\title{
The making of uniform costing in a war economy: The case of the Uniconti Commission in Fascist Italy
}

\section{Lino Cinquini}

Institute of Management, Scuola Superiore Sant'Anna of Pisa, Italy

\section{Riccardo Giannetti}

Department of Economics and Management, University of Pisa, Italy

\section{Andrea Tenucci}

Institute of Management, Scuola Superiore Sant'Anna of Pisa, Italy

\section{Corresponding author:}

Lino Cinquini, Institute of Management, Scuola Superiore Sant'Anna of Pisa, Piazza Martiri della Libertà, 24 - 56127 Pisa - Italy

Email:1.cinquini@sssup.it

This is a post-print version of the paper published in Accounting History, vol. 21 (Issue 4) pp. 445-471, DOI: 10.1177/1032373216652414, ISSN 1749-3374. 


\begin{abstract}
The paper analyses the experience carried out by the Uniconti Commission in setting rules of uniform costing in Italy during the World War II (WWII). This initiative was promoted by the Italian Fascist government and the Confederazione dell'Industria (Industry Confederation) in 1941. The purpose of the paper is to investigate the process of setting the uniform costing rules and "why" and "how" they were designed, according to a Foucauldian perspective that allows the problematization of accounting as a complex phenomenon, whose emergence and functioning is linked to the context and dependent on the interplay of different influences.

Starting from the aims inspired to the totalitarian ideology of the government that promoted the Commission, the analysis is grounded on archival primary sources and provides the perspective of the making of new accounting rules by the interplay among the participants acting in the process. This allows focusing the interaction between the domains of interests and of expectations - political-ideological, technical and economic that the process of setting the uniform costing system in that context implied. The outcome of the Commission represented a compromise between the stances of the accounting academy, the interests of business representatives, the dominant ideology and the political targets.

Thus, the paper provides insightful evidence of the complex interplay between knowledge, techniques, institutions and ideology in setting accounting rules in a totalitarian context, marked by a prevailing role of ideology and state in the regulation of economy.
\end{abstract}

\title{
Keywords
}

Uniform costing, War Economy, Accounting \& Ideology 


\section{Introduction}

The research presented in this paper is based on the documented experience conducted in 1941 by the Commissione Uniconti (Uniconti Commission). The Commission was promoted by the Confederazione dell'Industria (Industry Confederation) and by the Fascist Government to study uniform standardized procedures in accounting and schemes for financial and cost accounting practices. In this respect, the Uniconti Commission acted as an accounting standard setter in Italy during the WWII.

In reporting this experience, the research contributes to shed light on the relationship between accounting and society, in a way that makes accounting not a purely technical matter. The paper provides an interpretation of accounting change using a "genealogical" approach, i.e. by looking in detail at the archival documents related to cases or events at one period in the history of accounting, and examining the interplay between knowledge, power, techniques, institutions of the context (Foucault, 1977; Loft, 1986; Hopwood, 1987; Miller and Napier, 1993; Kearins and Hooper, 2002). Most of the "genealogical" research in accounting history seeks to illuminate the power/knowledge relationships embedded in historical context and the role of accounting as a "technique of knowledge" through which power is exercised (Loft, 1986).

More broadly, this Foucauldian framework allows the problematization of accounting as a complex phenomenon, whose emergence and functioning is linked to the context and dependent on the interplay of many different influences. This perspective is far from that 
of accounting history interpreted as a deterministic, unidimensional linear progress, or accounting practices "as the timeless products of the need for information for decision making or control, or the push for efficiency." (Stewart, 1992). Thus, it contributes to the stance of "new" accounting history (Miller et al., 1991).

The Foucault's framework (1982) identifies the elements which are essential to analyze power relations, namely: the system of differentiations (e.g. cultural, economic or knowledge-based), the types of objectives pursued (e.g. maintain privileges or accumulate profits), the meanings of bringing power relations into being (e.g. by means economic disparities or by surveillance), the forms of institutionalisations of power (e.g. through law), the degrees of rationalisation for the exercise of power (Kearins and Hooper, 2002).

In the paper, a description is made of the context under which the new accounting rules and techniques were fixed by providing a documented account of the ideological and historical conditions of the period and by analysing the documental evidence of the work of the Uniconti Commission to set the uniform accounting rules. Further, starting from the aims of the Italian fascist government that promoted the Commission, the different interests and knowledge expressed by the participants to the process are unveiled. Thus, the visibility of the interplay among the actors of the process of rules setting (the German ally, representatives of institutions, academy and enterprises) highlights the interaction between the domains of interests and knowledge - political, ideological, technical and 
economic - in that process of setting a uniform costing system. Through the minutes of the Commission meetings, these different roles are depicted in action into the dynamic of making the new accounting rules.

This way, the research on the Uniconti Commission highlights the dialectic among different actors participating and the presence in the accounting discourse of a complex interaction between knowledge, interests, institutions and ideology. The dynamic of this interplay is at the base of the possibility to appreciate accounting as a social - not merely technical - activity (Loft, 1986).

In this exploration the paper also provides evidence of the impact in the accounting field of the prominent role of the State in the last century, especially in the period of war economy (Armstrong, 1987; Loft, 1986), recognizing this role as a driver of change in accounting practices within a definite historical, political, and ideological context (Gilling, 1976; Hopwood et al., 1979; Miller, 1990; Miller et al., 1991; Canziani, 1994). In particular, the paper contributes to this theme with reference to one of the European States experiencing a socio-political context of totalitarism between the two World Wars. Accounting in such a context is still little explored in accounting history. Although the theme of accounting and ideology has been faced in accounting from different perspectives (e.g. Anthony et al., 1982; Robson et al., 1994; Cooper, 1995), few studies have been conducted in accounting history to explore the relationships between the totalitarian ideology of the State that affected a significant number of the European 
countries between the two World Wars, and accounting. Among these, Walker (2000) documented how the $5^{\text {th }}$ International Congress on Accounting held in Berlin in 1938 represented for the Nazi regime a significant opportunity to promote the national socialist ideology applied to the development of accounting, while Cinquini (2007) explored how the strong ideological commitment of Fascism had an influence on the field of accounting and business studies in Italy, on the degree of adhesion to the 'corporative' ideology of part of academics and on subjects and post-war development of accounting and business research in Italy. With respect to the research stream on the linkages between the ideology and accounting in the totalitarian State of the last century, this paper contributes by considering the importance of ideology in the process and direction of change within the accounting domain. In shedding light on the influence the German ally had in the work of the Uniconti Commission in the development of uniform costing rules in Italy, a facet is unveiled on the role the ideological foundation of the State may play in the accounting discourse: the political and ideological affinity between Italy and Germany at that time, in fact, constituted an influencial condition in the Italian process of accounting rules setting described in the paper, considering also the results that Germany had achieved in accounting standardization.

Further, the experience of the Uniconti Commission supplements and enriches the accounting history research on the uniform accounting movements that characterized the industrialized countries since the beginning of the last century (Mueller, 1965) within 
different institutional contexts and with different aims (Mitchell and Walker, 1996 and 1997; Ahmed and Scapens, 2003; Zelinschi, 2009; Singer, 1943; Solomons, 1950) ${ }^{1}$ More broadly, the research contributes to the stream of accounting history research on the accounting trends that significantly characterized the industrialized countries since the beginning of the last century (Bisman, 2012).

In this respect, this study further disseminates and extends the findings of an Italian article (Cinquini et al., 2009). The previous research has been theoretically refocussed, enriched, refined and integrated with further archival evidence and interpretation of the findings. The "genealogical" perspective adopted in this paper aims to investigate the power/knowledge relationships (ideological, political, economic and academic) among the actors involved in designing accounting rules. Therefore, new evidence concerning the Italian government, the academicians and the business representatives were extracted, analysed and interpreted from the documents database used in the previous research (Cinquini et al., 2009). This new documental analysis has highlighted the influence of the different actors - with their objectives and the emerging of power relations - on the design of accounting rules. In this way a new contribution has been obtained, illuminating the presence of a complex interaction between knowledge, interests, institutions and ideology in the accounting discourse.

The remainder of the paper is structured as follows. After a section in which the method adopted and the documental sources are discussed, the paper presents a section with the 
background of accounting standardization in Italy between the two World Wars. The subsequent sections are based on the archival documents collected: the fourth section deals with the expectations of the government in establishing the Commission and the influence on its work of the previous German experience in uniform costing, by reporting the evidence of a specific bilateral meeting in 1942; the fifth section focuses on the expectations and interplay among the main actors of the process (politics, business, academy). The sixth section provides insights in the orientation of the accounting solutions, presenting a discussion of the critical aspects of the main documents constituting the outcome of the Commission. These considerations will be the basis for

the discussion and conclusions section, based on the significance of the Uniconti Commission experience in the ideological, political and economic context in which it was established and worked and on the contributions of this paper in accounting history research.

\section{Research method and archival sources}

The methodological perspective assumed in this investigation, as aforementioned in the Introduction, is that of the "new accounting history" realm (Miller et al., 1991), i.e. a critical research "grounded firmly in the archive" (Carnegie and Napier, 1996). In the vein of "new accounting history", research breaks away from the traditional evolutionary 
approach of "reading the past in the light of the present" and aims at looking for interactions within space and time in which accounting developed.

In particular, this paper can be considered within the "critical history" stream of research, as it aims at emphasizing the relationship between accounting and its organizational, social and political content and the extent at which accountancy may reflect and influence the economic, institutional, political and social environments (Burchell et al., 1980; Hopwood, 1983; Previts et al., 1990a; Carnegie and Napier, 1996, 2012; Fleischman et al., 1996; Parker, 1997, 1999; Napier, 2006). Changes in theory and practice of accounting are not considered as occurred in a vacuum, but are rather influenced by the dynamics of (public or private) institutions that claim a social, political and economic role: their interactions carry out a regulatory function on accounting theory and practices. Therefore, institutional, social, economic and political conditions have to be extensively considered and understood for a study of trends and change in accounting theories and practices (Hopwood et al., 1979; Hopwood, 1987).

In reporting and interpreting the work performed by Uniconti Commission the paper adopts a narrative research approach aiming to establish and/or describe items of fact and to relate episodes in a particular, specific, non-analytical manner. This narrative approach is considered as opposite to approaches in history which are rigorously patterned in the investigative style of the physical sciences (interpretational) (Previts et al., 1990a; 1990b). 
In this research, the narrative is rooted on primary sources gathered in the Historical Archive of Confindustria (the Italian industrial confederation of entrepeneurs). In this respect, it can be considered in the stream of those studies in accounting history concerning accounting rule-making, in which "(...) it is important to enquire into what factors have impacted on the growing concern with the standardization of accounting practice in both the private and public sectors." (Carnegie and Napier, 1996: p. 25). This way, the relevance of the contribution that an archival research may give to the accounting history finds confirmation, particularly if conducted with reference to the period between the two World Wars in Europe.

An ad-hoc accounting standard setter is considered (the Uniconti Commission) in its establishment and work by using primary archival sources. In fact, the research is based on documents, minutes and letters reporting the work of the Commission and on the papers related to the issues found as annexes to the minutes. The archival sources examined are listed in Appendix $1^{2}$. In addition, secondary sources have been considered, namely publications of Italian Scholars reporting on that experience and other books and papers on the accounting topics under discussion.

Considering the archival sources, two main stages can be identified in the rules- setting work carried out by the Commission in the period 1941-1942. In a first stage the Commission worked having more operating purposes and defined general principles to 
unify accounting practices for all the industry sectors, with a total of 13 meetings since December 13th, 1941 up to September 17th, 1942 (see Appendix 2).

Then a second work stage began. The Commission created special Sub-Commissions for categories of businesses, whose task was to resolve the specific problems of the specific industry sector based on general preset criteria. A total of 40 Subcommittees were established, only 23 of which actually operated and delivered its report to the Commission. The work of the Commission was focused on the manufacturing industry, with the explicit exclusion of banks and insurance companies from the accounting unification project, and with the indication to postpone its application in commercial companies to the future. The idea of focusing on accounting unification efforts in the manufacturing industry was connected with the public procurement sector, consistently with the Government objective: to reduce public expenditure, mainly due to the war, through a control of the pricing processes and, consequently, of the prices of suppliers. The dramatic war events escalation in Italy in 1943 stopped the project, which was never resumed afterwards and did not produce factual results, as there were no time and space for implementation.

Before deepening the content of the documents and their interpretation in the aforementioned perspective, in the next section a concise background on accounting standardization in Fascist Italy is provided as a contextual frame. 


\section{Backgrounds: the issue of accounting standardization in Fascist Italy}

After Mussolini's rise to power in 1922, a new economic policy agenda was issued in Italy in the name of the building of the "corporative economy" that was tentatively developed throughout the ' $30 \mathrm{~s}^{3}$.

Notwithstanding the role of this 'revolutionary economic project' assumed in the propaganda of the regime, the "Fascist corporations" as representatives of economic categories of different trade and industrial sectors never became strategic centres of the national economy, and the debate they spurred was seldom of any relevance in practice. Their activity was mostly of a consultative nature, while the issuing of rules regulating economic activities in different sectors - the real 'revolutionary' issue - was very limited (Cassese, 1974; Franck, 1990; Aquarone, 2003: pp. 193 and ff.). Fascist corporations allowed social conflict to be appeased in a context of internal and international economic difficulties, while the real centres of power were elsewhere in banking and industry. They were especially located in the State owned firms, the most effective instruments of the Italian Fascist State's interventionist economic policy. IMI (Istituto Mobiliare Italiano) was founded in 1931 for the purpose of relieving the banking system of the pressure that arose from the large demand for loans from enterprises, by granting them long-term loans. This action was, however, insufficient and the situation of the banks that also owned shares in firms deteriorated until 1933, when IRI (Istituto della Ricostruzione Industriale) was instituted in order to cut the ties between banks and industry. IRI bought the shares 
from the banks with the intention of giving them back to the private entrepreneurs after restructuring the firms. Instead, in 1937 IRI became a permanent institute with the objective of assuming additional participation in great industrial firms involved in national defence, autarky and the valorisation of the (Fascist) Empire.

In the end, the "corporative" economic system in action proved to be primarily bureaucratic in its nature and effects; the actions carried out by Fascist corporations (drainage in certain parts of Italy, settlement of disputes between manufacturers, rationing control and retail prices, bank control, mandatory unions) were neither particularly original, nor effective.

Nevertheless, the development of corporative economy and fascist ideology did not keep accounting and business studies free from influence. Several scholars tackled general corporative economic issues and the relationship with business economic disciplines. The subject of "Corporative economics" was a recurring topic in the Italian Accounting Review (IAR) and in other publications of the '30s (Cinquini, 2007).

Among the recurrent themes, the 'problem of costs' and 'standards' was considered central to the development of an economic policy for the planning and statutory requirements gradually established (credit sector, import/export, taxation, prices) (Donnini, 1938; Santarelli, 1938a and 1938b; Trovati, 1938).

It is also worthwhile noticing that significant academic contributions to the debate on costing were produced in the Thirties in Italy. Although the accounting history research 
in Italy has been largely focused on the development and heritage of Zappa's thought, namely on the revolution of 'income-based accounting system' and the establishment of Economia aziendale ${ }^{4}$ (Canziani, 1994; Galassi, 2002; Antinori, 2003: pp. 43 ff.), in this period works on cost issues - that would later prove to be essential references in Italy after the Second World War - were published (Viganò and Mattesich, 2007). Publications of Italian scholars such as Pacces (1934), D’Ippolito (1935), Giannessi (1935 and 1943), De Minico (1935), Ceccherelli (1936), Amodeo (1941), all dealt with such issues from different perspectives ${ }^{5}$.

The gradual increase in size of manufacturing firms in the Italian economy also affected and spurred developments in the literature, due to the new control issues that were being introduced. Furthermore, the war economy stressed the significance of cost related to the perspectives of economic planning and regulation, as it was experienced by the development of unified accounting in Germany (Amaduzzi, 1943). After the entering of Italy into WWII (June, $\left.10^{\text {th }}, 1940\right)$ the quest for setting uniform accounting rules became unequivocally urgent in the Italian fascist government agenda. Thus, cost accounting standardization became a way to contribute to the institutionalization of the Fascist regime power (Kearins and Hooper, 2002).

The next section explains the reasons of the establishment of the Commission by the Fascist Government and the importance that the longstanding experience of the German ally played in the development of its work. 


\section{The role played by the Fascist Government and the German ally}

In a meeting held on November 29, 1941, the Council of Ministers of Fascist Government entrusted the Ministry of Corporations (Ministero delle corporazioni) with the issue of setting the rules to unify accounting and costing practices in the Italian industry. On behalf of the Ministry of Corporations (Minister Renato Ricci), the Confederation of Industrials founded a central organ called "Central Commission for accounting unification", also named Uniconti.

The reason for the introduction of a uniform accounting system is expressed in a letter, dated December 29, 1941, sent by the Minister of Corporations to the Ministry of Finance, the President of the Council of Ministers, the Minister of Justice and the Fascist Party National Directorate. In this letter, the need for a measure by which the Ministry of Corporations could have the power to issue "provisions for the unification of accounting systems" is mentioned, together with the reference to the German experience:

“... such a measure responds to the requirement for simpler tools to control production costs, in order to better regulate maximum selling prices. The concrete provisions that will be issued for this purpose are currently being prepared by taking into account the results achieved with the German experience. In particular, the aim of these principles, in addition to simplifying production cost control in order to fix better selling prices, 
is to provide appropriate comparison to determine the costs incurred by the same enterprise in different time periods and the costs incurred by other companies of the same industry sector over the same time period. Through a technical and administrative rationalization of manufacturing and trade businesses, and by keeping analytical records of each individual production cost item, production processes may also be controlled in order to evaluate their economic convenience" (LET., Ricci, December 29, 1941, pp. 1-2).

The intentions of the Minister of Corporations highlight the general purposes of the initiative: to control enterprises, within the framework of a corporative economic policy, without any explicit reference to the war economy, but rather emulating Germany practices. Since the beginning, Germany is addressed as the experience to consider for the Italian initiative.

Looking at the documents related to the establishment of the Commission, the correspondence between the Minister of Corporations and the Minister of Justice (Achille Grandi) shows different interpretations as to the role of the State in the economy of the corporative system (Santomassimo, 2006). Minister Grandi emphasises the fact that the provision was intended to limit the "regulation of maximum sale prices", therefore having a temporary "objective closely connected with the specific conditions of the war period" (LET., Grandi, January 10, 1942). The Minister of Corporations on the contrary suggests 
a much more ambitious objective of "controlling production processes in view of economic convenience" that may be supported by the accounting unification (LET., Ricci, December 29, 1941).

After its establishment, in a letter dated January 12, 1942 sent to Renato Ricci (Minister of Corporations) to submitt its work plan, the Commission stated its intention to follow the method already used in Germany, as its consolidated experience since 1937. The German legislation on accounting unification was also discussed in several letters exchanged between the Commission and the Minister of Corporations. In a letter dated June 1942, probably sent by the secretary of the Commission (Guido Carli) to the Minister of Corporations, we read:

“...I also considered the option of sharing the main rules issued in Germany in this field, so that the Ministry's technicians may examine the project by taking into account the German experience. In this respect, I think that a direct contact between the office of the Ministry and the offices of the Confederation responsible for the study of business accounting issues is desirable. A joint debate could bring about improvements to the project" (LET., Carli, June 1942, p. 1). 
The relevance of the influence of the German experience in the work of the Uniconti Commission is supported by the presence of three additional documents in the archive folder on which this research is grounded.

The first bears the title "Position of accounting in the framework of the German rationalization movement" (without author nor date) and consists of a long introduction to the accounting unification process carried out in Germany to reorganise the industry in view of achieving the highest possible manufacturing efficiency level in enterprises. This document covers the fundamental stages of this process.

The second document, called "First report to the Minister of Corporations on the unification of accounting in Germany" (without author nor date), details the criteria followed by the Reich to identify a unified scheme for cost accounting. Guido Carli might have written the document, since pieces of its contents can be found in an article (Carli, 1941).

The third document, "Use of the depreciations of industrial companies for financing the war", dated January 28, 1942, is the translation of the "NeueZürcherZeitung" of January 21, 1941, where the proposal on depreciation developed in Germany by the Vienna economist Nöll v.d. Nahmer (published by the journal "Die Deutsche Volkswirtschaft" of December 1, 1941) is discussed.

Contacts between Germany and Italy on these issues closely connected with the work of the Commission were intensified, so that the Reichsgruppe Industrie and the Fascist 
Confederation of Industrials held a conference in Rome on May 26 and 27, 1942. During this meeting, the representatives of the two organisations exchanged views, particularly about price determination and control in the manufacturing industry.

The President of Reichsgruppe Industrie, Zangen, illustrated the economic pricing policy implemented by Germany in detail: the Reichsgruppe Industry worked as a consultant for the Price Commission in every circumstance - he stated - and industry was involved in all the issues that regarded prices (DOC., "Minutes of the second meeting held by the Fascist Confederation of Industrialists", May 26, 1942). This contrasted with the strictly hierarchical price determination and control method used in Italy so far. The formerFinance Minister and President of the Confederation of Industrials, Giuseppe Volpi, also took the floor at the conclusion of the meeting and expressed the following considerations about the Italian system based on the German colleague's views:

"I believe that this system [in Italy] cannot be used in the long-term and needs to be reviewed" (DOC., "Minutes of the second meeting held by the Fascist Confederation of Industrialists", May 26, 1942, p. 14).

What appears from these sources is that the aims given to the Italian uniform accounting and costing systems were multiple in the minds of the governmental actors that lead the process. Althought the Uniconti Commission was primarily promoted by the Italian 
Government for reasons related to the wartime need of control on job prices, part of the leaders of the Fascist regime considered uniform costing as a fundamental accounting device for implementing a new interventionist economic policy. This initiative was seen indeed as the possibility of a "further step forward" toward the making of the "fascist corporative economy'. The pressure by Government to embed these objectives into operative statutory rules represents one relevant element to analyze the power relations among the actors involved into Commission's activity (Kearins and Hooper, 2002). Another point is that Germany was considered as the main reference for the Commission's work since the beginning of the initiative. This circumstance is certainly related to the ideological and political alliance between the nazist and the fascist regimes at the time. Beside this, it is a matter of fact that when Italy faced the price control issues of the war economy together with the problem of standardising accounting practices, the German ally already had a long-term experience that represented an important reference. In fact, the German economic system at the beginning of the Second World War had experienced significantly advanced uniform accounting processes, both in financial reporting and costing. They were realized through an elaboration started since 1914-1915 in a well prepared context (Carli, 1941), as the result of a co-operation between companies and private groups, institutions and universities long before the rise to power of Nazism. Afterwards, a further development was impressed by the nazi centralized economic policy (Frei, 2002): uniform accounting, which had been a voluntary choice until then, became 
mandatory within the context of the controlled National Socialist economy and a tool of its economic policy (Matz, 1940a; 1940b).

In Italy, on the contrary, no statutory requirements were developed for accounting in the Thirties, a definitely different situation than in Germany. Companies had extensive freedom to select their preferred criteria, accounting methods, charts of accounts, costing methods, financial reporting forms, according to the principles that seemed to them to be the most appropriate for their organisation and for the purposes of each individual enterprise (Fabrizi, 1942: pp. 1-2).

The reason of the different development of uniform accounting between Italy and Germany is twofold. A first reason can be addressed in the different types of economic policy and regulation mechanisms that prevailed in the two countries. In Italy, as aforementioned, the direct intervention by the State in certain sectors of the economy was realized through State-owned companies (such as IMI and IRI), differently from Nazist Germany, and this implied the development of specific regulatory and governmental tools. The issue of cost standardization was more urgent in Germany due to the need of regulating prices and eliminating extra-profit in large private monopolistic companies, while in Italy these companies had become State owned and played a pivotal role in the industrial development in the Thirties (Carli, 1941: p. 6). A secondary reason is related to a general suspicion of the Italian academy toward the excess in regulation of business activities $^{6}$, even in the ideological prominence of Fascist ideology. 
These were the reasons of the different stage of development of uniform accounting between Italy and Germany. The position of Italy appeared backward with respect to Germany in this field as evidenced by the reports of the conference held in Rome in 1942 , according with the different paths toward standardization followed by the two countries and the differences in price determination and control in the manufacturing industry. Hence, another point emerges affecting power relations according to Foucault (1982), namely the system of differentiations (Kearins and Hooper, 2002). In the case of "Uniconti" Commission there were relevant differences between Italy and Germany (economic and cultural) and this was a premise to the dialectic among these actors involved in the Commission activity.

\section{The role played by business representatives and academics}

The members of the Uniconti Commission were academicians in accounting and Economia aziendale, chartered accountants and managers of manufacturing companies ${ }^{7}$. There is no evidence in the source documents about the criteria followed for the selection of the academics and the chartered accountants in the Commission. The origin of the accounting profession in Italy can be located in the first decades of the XX century, in a period in which the Italian industrial revolution was completed, business studies had a further progress and Higher Schools of Commerce had a considerable diffusion. Nevertheless, only a decree of 1929 determined the origin of the actual Order of chartered 
accountant profession (Camodeca, 2005). From the documents collected it seems that the involvement and the contribution of the accounting profession in the Uniconti Commission were not relevant. The accounting profession in Italy had been formally established not so far before the establishment of the Commission, and therefore it did not have a recognized institutionalization and influence in the domain of the standardization of accounting principles promoted by the Government.

The role played by the representatives of the Italian academy in the Commission ${ }^{8}$ in the making of these accounting rules is clear since the first meeting, when principles and times of conducting the work were defined.

We read in the minutes of the first meeting a speech pronounced by Prof. Onida, who was the chairperson of the meeting and had the task of planning the work:

“...In the end, Prof. Onida summarised the discussion as follows:

(a) We have the problem of trying to standardise administration practices (financial accounting, cost accounting, and connections between the two);

(b) We have the problem of trying to standardise cost recognition criteria. There are as many cost configurations as purposes. For example, the costs arising from financial accounting - in which the costs incurred for the achievement of a certain product contrast the revenues achieved with the sale of the same product- do not provide indication for the purposes of pricing policy; for these purposes we will have to assume 
the cost as determined on the basis, for example, of materials evaluated not at the purchase price but at the repurchase price" (MIN., first meeting, December 13, 1941, p. 2).

In other occasions, the curiosity of the researcher seems to mix the necessary pragmatism drawn from the situation. In the fourth meeting of the Commission, attended also by some iron and steel industries, an issue raised which stirred Prof. D'Ippolito's interest, i.e. the link between financial and cost accounting:

“Prof. D' Ippolito took the floor and pointed out that it was time for attendees to express their opinions about methods to connect financial and cost accounting practices. Since such a connection could strongly affect the structure of financial accounting, it would be impossible for the Central Commission to formulate broad principles of financial accounting unification without having clarified this aspect first" (MIN., fourth meeting, January 15, 1942, p. 5).

Finally, the commitment of academicians in the creation of a common technical language to be shared by all the participants appears evident: 
"While a study will be carried out on each individual sector of the industry, the Central Commission will select uniform cost accounting criteria. For this purpose, professors D'Ippolito, Onida and Pacces have been invited to draw up a terminology unification draft" (MIN., third meeting, December 23, 1941, p. 6).

The acknowledgement of the role of academicians emerges also at the end of the eleventh meeting of the Commission, where the guidelines for the work of Sub-Commissions were traced. A university professor member of the Central Commission was entrusted with the role of chairing the Sub-Commissions (MIN., eleventh meeting, May 1, 1942, p. 1), thus contributing to add consistency to the scientific foundation of the solutions proposed. In sum, the Italian accounting academic community offered a scientific contribution on the relevant accounting themes of the Commission, as we will discuss widely in the following section.

Concerning the role of business representatives, it is noteworthy a difference between the attitude of German and Italian entrepeneurs toward the accounting standardization initiative.

German manufacturers' associations played a significant protagonist role in the development of uniform accounting schemes far before the advent of the Nazi regime, particularly in the steel and machinery industries ${ }^{9}$. According to the considerations of the president of the German manufacturers' associations, Zangen, presented during the 
already mentioned meeting held between the German manufactures and the Confederazione dell'Industria (hereinafter: Confindustria) on May 26-27, 1942:

“ (...) in cost control and pricing, we are proud to be able to say that we have achieved a significant success, particularly due to the pre-existing control organization and to the manufacturers' self-discipline. (DOC., "Minutes of the second meeting held at the Fascist Confederation of Industrialists", May 26, 1942, p. 1)

On the contrary, Italian Confindustria did not appeared fully convinced about the aims of the initiative of the Uniconti Commission. It was perceived as potentially dangerous, both in the control exercised by the State on the businesses' management boards and in the practical enforcement of the new principles. In this respect the industrial organizations were feared that it could be applied with the aim of increasing the tax area.

Aware of this feeling, since the first meeting held on December 13, 1941 Giovanni Balella, General Director of Confindustria, during his introductory speech invited the Commission, “... to develop a unification program, without being distracted during the development of the work regarding the objectives that unification should fulfil in the Ministry's mind". The concern we read in these words also echoes in other minutes of meetings held by working groups and representatives of the businesses. 
The meeting minutes reveal the frequent criticism and concerns expressed by the representatives of Italian enterprises about the fiscal implications of accounting unification.

A first issue was the fear that the tax burden could increase, looking to what had happened with the accounting unification process in the war period, as the German experience had showed:

“... from the components referred to the manufacturing industry (Ghezzi, Ghiglione and Teani), we have serious concerns for the possible tax implications of unification" (MIN., first meeting, December 13, 1941, p. 2).

"During the debate, the representatives of the hydroelectric companies expressed their concern about the tax implications that may result from unification" (MIN., second meeting, December 22, 1941, p. 2).

"The attitude of Sub-Commissions in respect of the unification movement is largely influenced by the tax concern" (DOC., "Note for the Director", November 9, 1942, p. $5)$.

A second set of worries of the industrial representatives was strictly operational in nature, but in the Commission's opinion it would have heavily affected the implementation of a 
unified accounting system. These problems were highlighted in a note for the director of the Confederation, dated November 9, 1942 (when the work was almost completed):

"Most reports delivered so far describe the enormous technical difficulties companies would face in the event that unified accounting schemes were enforced immediately, and this for two reasons: a) lack of administrative staff, determined by the current war contingencies; b) lack of qualification for most small and medium size companies (whose accounting systems are rather rudimentary) to apply the unified schemes" (DOC., "Note for the Director", November 9, 1942, pp. 5-6).

The worries of the industrial representatives about the tax implications and the difficulties affecting the implementation of a unified accounting system relate to the objective of firms to preserve profitability. This objective contrasts with those of Government and represents a further element useful to explain power relations (Focault, 1982) and to understand why the unified accounting system was settled in the way explained in the next section.

Furthermore, according with the Fascism historiography, another circumstance that is important about the role of entrepeneurs' representatives in the Uniconti Commission is that Confindustria substantially acted as an operating instrument used by the Ministry of Corporations to govern the economy during the Fascist era (Rossi, 1966; Santomassimo, 
2006). In fact, since the so-called 'Palazzo Vidoni Pact' with Fascism in $1925^{10}$ Confindustria became an institution "enjoying both the independence of a private organization and the power of a public institution" (Sarti, 1971: p. 14). Confindustria was entrusted with the daily management and direction of the entire economic mechanism, and its technical offices became a sort of operational staff of the Fascist corporations. In the case of Uniconti Commission experience, it is understandable that the Fascist Government considered the cooperating role of industrial organizations crucial for the implementation of a uniform accounting plan useful for the economic policy - as the German experience had widely demonstrated. Nevertheless, the evidence of the work in the Uniconti Commission shows how the commitment of industrials in the attempt of developing accounting standardization in the Italian context was problematic.In Italy the issue of accounting standardization had not been developed gradually as in Germany, and the entrepeneurs remained suspiciuos toward the State intervention. We can also perceive by the evidence the limited penetration of the 'corporative ideology' in the capitalistic class in Italy at that time, although it was supporting the Fascist regime (Rossi, 1966). Hence, Confidustria can be considered for the Fascist regime as a way of bringing power relations into being (Focault, 1982), even if the mindset of Italian capitalistic class made it more difficult than in Germany and required a different approach.

\section{The outcomes of the Commission: cost accounting rules between economic rationality and State-intervention ideology}


In the previous sections, the main expectations from Government and Business representatives addressed toward the uniform cost system and the cultural and economic differences between Germany and Italy have been discussed.

The evidence shows that the purpose of the Government for the uniform costing system adoption was twofold (LET., Ricci, December 29, 1941, pp. 1-2; LET., Grandi, January 10, 1942). From one side, it was considered as a tool for controlling enterprises within the framework of a corporative economic policy. In this view it was a "mechanism" useful for implementing ideological constructs and political targets in the real world. From another side, the Goverment was interested to control war expenses and to reduce as much as possible inflation. In this perspective, the uniform costing system had a more contingent role.

Business representatives appear more as counterpart than as allies or partners of the Government. They wished to fix cost accounting rules for economic reasons, since they tried to maintain/increase the profitability of the firms (see, for example the fears by the industrials toward the tax burden, above mentioned).

Academicians in accounting and Economia aziendale had to manage their position within the match between these two parties remaining consistent with their doctrinal background. Furthermore, as documented, the process of cost accounting rules formulation was influenced by the German experience, even though there were some relevant differences between the allies. How did the German experience and the 
differences in the objectives of each actor involved in the Commission's work affect the cost accounting rules proposed by the Commission?

In order to provide an answer, the two documents produced by the Commission and the process behind these documents are examined in this section. To facilitate the interpretation of the primary sources, we will use also as a secondary source an article published at that time (De Minico and D'Ippolito, 1943), whose purpose was just to analyze certain subjects related to the Commission's work. This article is dated September 1942 (published in 1943) and one author (Teodoro D'Ippolito) was a member of the Uniconti Commission.

Sources are examined considering the following issues:

- the cost accounting principles;

- the cost accounting system;

- the depreciation rules;

- the relationship between product costs and prices.

\section{The cost accounting principles}

The guidelines for calculating product costs are included in the document entitled "Criteri per la determinazione dei costi come base per la fissazione dei prezzi dei prodotti nelle vendite da parte dell'industria" [Costing principles to be used as a basis for fixing the prices of products to be sold by the industry, hereinafter: "Costing principles"]. The parts of the document useful to be analysed to explain the match among different forces 
involved in the costing system design may concern: cost objects, purposes of the costing systems, allocation methods.

For each of these topics the main points are recalled and discussed to point out if and why actors involved in the costing system design may have exerted pressure toward certain solutions.

Reading the "Costing principles", it emerges that usually specific products are considered as cost objects, eventually group of products or product lines (e.g. in the case of joint products); sometimes also activities enclosed in the production process may be a cost object (“Costing principles”, p. 3; De Minico and D’Ippolito, 1943: p. 66). Evidence showing different views of the parties involved in the design of the costing system were not found about the cost objects.

The document specifies that cost determination has the main purpose of obtaining a basis for fixing prices by a mark-up that may allow a profit to the organization to be economically self-sufficient (Costing principles: p. 3). In other words, prices should allow an organisation to be "wisely administrated" over a length of time with no economic help from outside, i.e. having the necessary financial resources to face changing market conditions. For this purpose, repurchase or reconstruction values are admitted in costing practices, whenever required. This cost accounting rule is extremely conservative, both for the profitability of firms' owners and for the autonomy of economic system. Therefore, this solution met the needs of the Business representatives and the 
Government. From a theoretical perspective it could be controversial, as it does not reflect the actual costs incurred by companies to carry out the production processes. Resources for replacing investment may be obtained by provisions and in a market economy funding to repurchase the inputs could derive from the owners and/or from banks, if the company is profitable. However, in the documents examined, there is not evidence of unfavorable comments from the academicians, probably because the solution adopted allowed the survival of business, it was viable to the corporative economy and more feasible with respect to other ways for replacing investments. Hence, it may have been considered as a "good compromise" for the actors partecipating to the activities of the Commission.

The costing system proposed faced the problem of cost allocation. The basic principle underlying cost allocation accepted by the Commission was the cause-and-effect principle (De Minico and D’Ippolito, 1943: pp. 66-67). According to De Minico and D'Ippolito's (1943) interpretation, wherever the cause-and-effect principle is not applicable, the Commission indicated as a reference the contribution capacity principle (which established that shares of indirect costs are allocated to the products according to their assumed "facility and rapidity of placement in the market"). As regard the cost allocation criteria the document highlights that no absolute criterion may be suggested:

"It should be recognised that no absolute criterion can be indicated for the allocation of common costs. Therefore, different allocation criteria must necessarily be figured 
out, provided that the sum of the shares allocated equals the total amount of (indirectly allocated) common costs that can be referred to the whole productions of the business over the time period considered. It is understood that, once a given common cost allocation criterion for the determination of the total cost of a given product has been accepted, this criterion shall constantly be applied for that product, even when the total cost of the other products has to be determined." (DOC., "Costing principles", 1942, pp. 3-4).

This piece of document recalls one aspect of Gino Zappa's thought. In Zappa's view (1937: p. 232 and the following), allocating margins (and consequently the respective revenues and costs) to the corresponding specific productions was the result of an abstraction, and also, in a way, of an excessive forcing of reality. In fact, as He points out, costs and revenues are interwined each other in space and time, so that their separation has to be operated with extreme caution and, in any case, without neglecting their interdependence. In this respect, the clarification on the costs assignment (both direct and indirect) reported in the document may be interpreted as the acceptance of a theoretical contribution from the academicians operating inside the Commission ${ }^{11}$.

Moreover, the quote above proves that there was a need to establish shared criteria for costing practices that State control authorities might assess (LET., Balella, February 19, 1942). Hence the maintenance over time of the cost allocation criteria facilitated 
verification and comparability of the data from the government, this could be useful to facilitate the functioning of the corporative economy. Therefore, it is plausible to assume that the criteria for the allocation of costs above reported have been accepted by the fascist Government as they were aligned with its political targets.

\section{The cost accounting system}

The document entitled "Ordinamento della contabilità generale e delle determinazioni dei costi nelle aziende delle industrie siderurgica e metallurgica" [General accounting and costing regulations applicable to the iron and steel industry, hereinafter: "Iron and steel industry cost regulation"] is the only detailed document available in the archive that was developed taking into account the previous general guidelines. The document bears no date. It was found in the historical archive of Confindustria together with the other records concerning the Commission, and its contents is in line with the main document concerning unified cost accounting by the same Commission. Therefore we believe that it may have been drawn up during 1942 - i.e. the year in which the Commission produced its main results.

As regards product costs, information is obtained according to the scheme presented in Figure 1. 


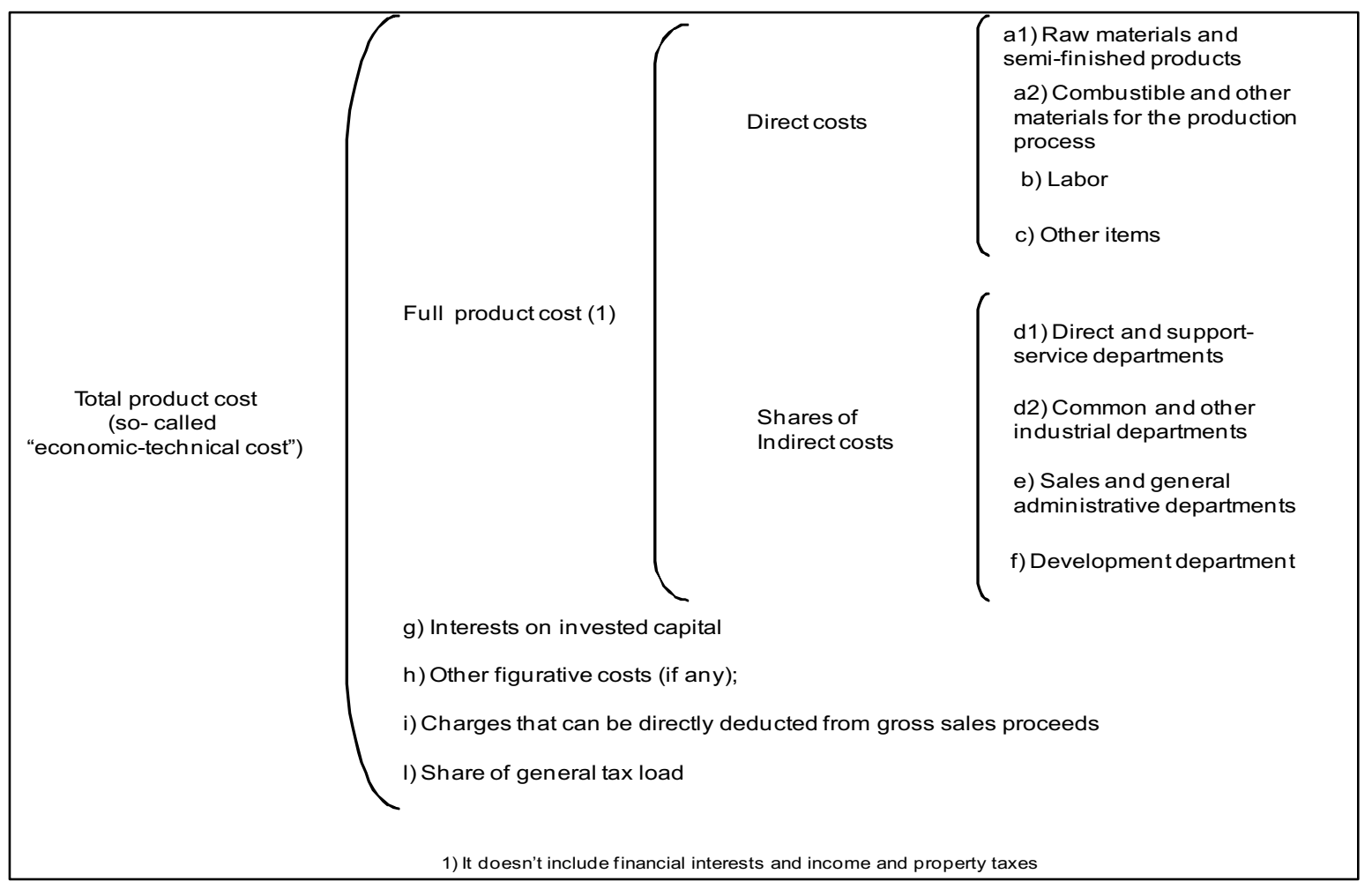

Figure 1 - Unified scheme of the product cost configuration for the organisations of the Iron and Steel Industry (source: DOC., "Iron and steel industry cost regulation": p. 14)

Based on the recommendations developed in the document, estimated costs should be performed according to the unified scheme described above for current costs. These costs would provide the basis for the determination of the prices to be set by companies in the Iron and Steel Industry. In the document it is recognized that costs must be used to set prices, so that a company may generally establish a suitable connection between costs and revenues to ensure long term survival of the business. 
The first reference to determine the amount of costs for each item is given by that existing at the time of estimation ("Iron and steel industry cost regulation": p. 30). But if the company can reasonably assume that costs will change in the future, then it may adopt estimated costs (as suggested in the "Costing principles" document).

The department (or cost centre) is the "elementary unit" considered to forecast indirect costs ("Iron and steel industry cost regulation": p. 32). It is worth to underline that also the German experience concerning the unification of cost accounting practices, was grounded on a "cost center-based-costing". Cost centers were used together with multiple overhead rates (as described widely in the DOC. "First report to the Minister of Corporations on the unification of accounting in Germany", n.d., p. 2). These similarities with German unified scheme may be a further element highlighting the influence exerted by the German experience.

Finally, the so-called "economic-technical cost" is obtained summing up the interest on invested capital, charges that can be directly deducted from gross sales proceeds and a "remuneration for the general economic business risk" (which is not explicitly indicated in Figure 1). The latter is determined by considering the future operating conditions of the organisation, according to its past experience and, again, by taking into account future economic perspectives ("Iron and steel industry cost regulation": pp. 31-32) ${ }^{12}$. The scheme includes a compensation for the owners; therefore it is possible to assume that it has been accepted from the Business representatives and the Government. In effect this 
scheme guaranteed a profit to the firms' owners and at the same time permitted to control the pricing of enterprises. This last aspect was relevant in order to have a costing system operating as a mechanism useful to realize a corporative economic policy.

\section{The depreciation rules}

As reported above depreciation may be a critical issue in the economy of war (see the document, "Use of the depreciations of industrial companies for financing the war", quoted above) because from one side it has an implication to the financing of war expenses, on the other side this conflicts with the interests of the firms'owners. But also from a technical point of view depreciation may be a critical point in designing uniform costing systems, because it is necessary to set shared and verifiable rules.

In the document "Costing principles" depreciation is distinguished according to different purposes (tax assessment, balance sheet and product cost). This distinction seems to be a first answer to the suspicions of managers and owners concerning the tax implications coming from the uniform costing system.

The sources examined include several parts useful to understand how the accounting rules concerning depreciation may be interpreted in the light of the influence of the actors involved. 
The importance attributed to the repurchase or reconstruction values to calculate depreciation is underlined in the minute of a meeting reporting the quote of a steel and iron company representative:

“(..) We will begin by unifying general accounting principles, and then pass to unifying cost accounting practices. Moreover, we shall discuss costing criteria. In this regard, Dr. Bellorini [Finsider Company] took the floor and expressed his vote, also on account of the iron and steel organisations not belonging to his group, that Confindustria should support the industrialists' point of view according to which depreciation should be mainly related not with plant current values of construction, but rather with plant re-construction values, keeping into account the currency depreciation value. In addition, interest on invested capital shall be related to the capital resulting from the revaluation of the company's business expressed in current currency value" (MIN., fourth meeting, January 15, 1942, p. 4).

The document on Iron and Steel industry accepted this observation: it asserts that in current cost calculation, depreciation usually is determined by making reference to the historical recording values, adjusted to keep into consideration any change in the currency purchasing power, if necessary. Regarding the estimated costs it seems possible to consider reconstruction or repurchase value, because the document affirms that future 
product prices (determined considering the production costs) have to permit to restore the assets used in the production process. Hence for this point the other members of the Commission shared the industrialists' point of view.

Another aspect concerns the incidence of the depreciation on the cost objects. Depreciation is a typical fixed cost, if the production volume change the incidence of this cost item on the unit product cost will change in an inversely proportional manner. The document on iron and steel industry allows current product costs to be determined fixing a "normal amount" of fixed cost, wherever production undergoes considerable fluctuations ("Iron and steel industry cost regulation": p. 25). A "normal production level" rather than the actual one determines the "normal amount" of fixed costs. This rule makes possible to stabilize the incidence of fixed costs onto product costs. Over allocations (current volume higher than normal) are compensated with under allocations (current volume lower than normal). Due to the stabilized incidence of fixed costs on units there is not price fluctuation depending on the reduction/increase of production volume. This could be a useful result for the Government in the wartime, when the trend of prices tends to increase inflation and war expenses. Moreover, companies could recover the cost incurred through the compensation mechanism. Thus, both the objective of the owners (economic interests) and that of the Government found a satisfying combination in this technical solution.

\section{The relationship between product costs and prices}


The uniform costing system proposed by the Commission had to support price setting. It is useful to analyze how costs have been connected to the prices and how the actors involved in that context influenced the adopted solutions.

The additional profit to product cost in order to obtain price may be considered as the "bridge" between product costs and prices. This amount is enclosed into the unified scheme (Figure 1) through the determination of the so-called economic-technical-cost as adopted by the Commission. According to the "Iron and steel industry cost regulation" (pp. 31-32) the profit enclosed into the economic-technical cost is determined by adding two components: the interest on invested capital and the remuneration for the general economic business risk. Interest on invested capital is obtained by multiplying the book value of the entire capital invested (recorded on the assets side and updated, if necessary, to keep into account the currency's loss of purchase power). The invested capital is determined taking into account the monetary depreciation, as a firm representative asked during a meeting of the Commission (above quoted), so that economic interests of the owners are preserved.

The rate to be applied to this capital is assumed identical to the rate determined "by the bank cartel for unsecured current account overdraft, inclusive of banking fees and charges" ("Iron and steel industry cost regulation": p. 26). No recommendation is given both on the share of interests between owners and other financing parties and on the 
calculation of the remuneration for the general economic business risk. This is just the amount of profit that, from a "technical point of view", should be used as a basis for setting prices. In defining this amount of profit there is space for adjustments due to the pressures of the parties involved in the Commission. For instance, how the weight for the general business risk should be set? This is a potential source of conflict between the State and the Business representatives (the first had the interest to reduce this weight, the second to increase it). Unfortunately there is no evidence on the discussion among the parties on this point. The only element that the Commission points out is that the product costs determined according to the unified scheme provide a basis for the determination of the prices to be adopted by the companies in the Iron and Steel Industry (DOC., "General accounting and costing regulations applicable to the iron and steel industry", n.d., p. 30). The fact that the product costs plus the compensation for the owners is addressed as the base for fixing prices and not the price to apply, gives space for some considerations. The first one is that the profitability rises from a comparison between the convenience of all the product prices adopted in a firm with all the product costs incurred, rather than from the tight correspondence one to one between single production costs (as determined according with the rules described before) and single price. This approach is aligned with Zappa's theoretical unitary view of the firm and reveals an influence from academia on the use of cost accounting information in orienting the price setting process. 
The second consideration concerns the elasticity in the connections between costs and prices, i.e. the maintainance of a range of possible acceptable solutions. This issue permits to integrate the objectives coming from corporative ideology and war economy government needs with those coming from the other actors involved in setting cost accounting rules. For the discussion of this point it is useful to report a concept that was explained in an article by De Minico and D'Ippolito (1943).

De Minico and D'Ippolito (1943: p. 63 and ff.) claimed that the degree of fullfilment of the needs of individuals and interest groups in a corporative regime aimed to obtain a "maximum distribution fairness in a maximum collective creation". The first goal was referred to a less arbitrary and "as fair as possible" redistribution of the wealth produced, while the second addressed the best possible use to be made of human forces and of resources available.

As to distribution fairness, unjustified over-profit was not admissible, where over-profits were those not obtained for an "exceptional efficiency improvement activity"13. When over-profits were justified, they were considered as a significant incentive for business to improve its production conditions. However, such incentives are not a permanent rule, but should have lasted until an "ethical-corporative awareness" would be developed as a shared ideology in the economic system.

Thus, taking into account product cost information, prices may be selected in order to get superior aims such as the "maximum distribution fairness in a maximum collective 
creation" (or for facing urgent needs linked to the war). In other words, in order to get superior aims, it is possible for any given product to fix a price different from the product cost-plus the profit determined according to the unified system. This leads us to consider at least the following alternatives (Jucius, 1944: p. 43):

- $\quad$ the use of the price of the marginal business;

- $\quad$ the adoption of a single price defined by making reference to a specified business, selected according to predefined criteria;

- $\quad$ the use of a single average price for any given product.

The choice among these three may be influenced by ideological and political reasons. If the target would be to use the entire productive capacity available (e.g. in the war time) the price for the same product realized by different companies, should be established according to the marginal business, i.e. the price of the less efficient company.

Vice versa, the target could be efficiency over a given historical period: in this case a low price of a company representing a sort of reference (benchmark) should be identified in order to improve the productivity of the system in the medium-long term.

Instead, if an average price is set, this means that a mix of the previous objectives is pursued. In each of the alternatives, the most efficient businesses realize profit levels greater than expected and this effect satisfies the ideological concept of "maximum distribution fairness" as highlighted by De Minico and D'Ippolito (1943). 
The Commission did not face the problem, however it was a question surrounding the the use of uniform cost system, as it emerges from the following quote:

"The only possible solution seems to be determining a single sale price referred to the production cost of the marginal business. (...) This will necessarily determine revenues for the businesses located on the positive side of the margin - moreover, such a phenomenon is susceptible of producing useful economic effects, as it provides the strongest possible incentive to improve production processes. This is the view adopted in Germany to replace the old approach, also for the purpose of determining the price of government procurement. As it is well known, according to the provisions contained in the fundamental legislation in this field, the prices of government procurement contracts are proportional to the production costs of individual suppliers, so that as many prices as suppliers would be fixed. (...). This would have the purpose of forcing less efficient manufacturers to improve their production processes (...)" (DOC., "Observations on production cost to be considered for price setting”, n.d., pp. 1-3)

Given the basic economic principles that must be respected to allow the companies to survive, in cost accounting it is well known the possibility to make "different costs for different purposes" and the evidence proposed sheds some light on the rationale that was behind the exercise of power by the actors involved both in the design and use of cost 
accounting rules. The discussion we have provided on the cost accounting issues faced by the Uniconti Commission explores how power relations (ideological, political, economic and academic) affected these purposes and influenced the design of cost accounting rules.

\section{Discussion and conclusions}

In describing and analysing the experience of the Uniconti Commission in Fascist Italy, we emphasized the relationship between accounting and its organizational, social and political content (Burchell et al., 1980; Hopwood, 1983; Previts et al., 1990b; Carnegie and Napier, 1996, 2012).

This paper used a Foucauldian "genealogical" approach (Loft, 1986; Kearins and Hooper, 2002): by providing detailed insights on the Uniconti Commission experience in Italy on the base of a contextual analysis and an original archival documental sources listed in Appendix 1 (i.e. developing an accounting history research "grounded firmly in the archive": Carnegie and Napier, 1996), the accounting discourse is revealed as a complex phenomenon, whose development and change are basically linked to the context and dependent on the interplay of many different influences (Stewart, 1992).

As a first point, the research on the experience of the Uniconti Commission sheds light on the strenght of the State-interventionism embedded in the totalitarian ideology of Fascism in driving the setting of an uniform costing system. It provides evidence of the 
forms in which the interventionist role/regulatory function of the State in the economy manifested at the time. In both the totalitarian regimes of Germany and Italy between the two World Wars the standardization in accounting - although differently in the two countries - assumed a role for the implementation of a planned political economy, rationalization and regulation of industries, particularly in Germany. Further, the process of accounting change was driven by the issue of the conduct of war, where accounting was implicated in the control of a constrained war-time economy. In this respect, the paper contributes to the themes of the establishment of the State as an arena for the development of the accounting discourse and practice through an extended intervention and regulation of economic processes in the last century (Hopwood et al., 1979; Hopwood, 1987; Canziani, 1994). Further, the role that ideology may play in the accounting discourse is also revealed by the influence the German ally had in the work of the Italian Uniconti Commission. The totalitarian political and ideological affinity between Italy and Germany at that time and the results achieved in the German experience of accounting standardization made the interaction between Italy and Germany in the Italian accounting rules setting process highly influencial, as resulting by the minutes of the meetings. Thus, in understanding the influence of the State on accounting, the Uniconti experience addresses the importance of the ideological foundation of the State for the consequences that this may occur in the process and direction of change in the accounting domain. 
Secondly, the documented history of the Uniconti Commission shows the presence of a complex interplay of many different influences, which is at the base of the possibility to appreciate accounting as a social - not merely technical - activity (Loft, 1986), and accounting history as a complex, contextual and "plural" phenomenon - not a deterministic, unidimensional linear progress (Stewart, 1992). A frame of complexity and interconnection existing between ideology, knowledge, expectations and interests domains, accounting practices and their institutional contexts has emerged, providing in the research the picture that the "new accounting history" research aims to disclose in its approach (Miller et al., 1991).

In considering the different actors that participated in the process described in the paper (Government, business representatives and academics) the documental analysis has unveiled the underpinning differences, objectives, means of bringing power relations into being that influenced the outcomes. Considering this, the study further extends the previous Italian article Cinquini et al. (2009). To this aim, additional evidence concerning the Italian government, the academicians and the business representatives have been extracted, analysed and interpreted. The "genealogical" perspective adopted in this paper has allowed to investigate in depth the power/knowledge relationships among the actors involved in designing the accounting rules.

One first point in this respect concerns the multiplicity of objectives by Fascist Government in promoting the setting of the Italian uniform accounting and costing 
systems. As we read in transparency through the letters discussed in the paper, this initiative was seen as the possibility of a "further step forward" toward the making of the 'fascist corporative economy'. Although that choice was primarily promoted by the Italian Government for reasons correlated to the wartime need of control on job prices, in the context of the Fascist regime (or at least in part of their leaders), uniform costing appeared as a fundamental tool for implementing a new economic policy coherent with the corporative ideology.

On the other hand, the circumstance that the uniform costing was promoted in Italy much later if compared to the German political ally explains why Germany was considered as the main reference for the Commission's work since the very beginning of the initiative, and the importance given to the German experience. This difference in degree of development of the uniform costing design and implementation - as recalled in the paper - was due to the different economic policies of the two totalitarian regimes with respect to economy regulation.

In the process of setting a new uniform accounting system narrated by the Uniconti experience, besides the Government also the relevance of the Italian entrepeneurs association (Confindustria) and the Italian academics emerges.

Regarding entrepeneurs, if we consider the suspicions expressed by the Italian business representatives in several Commission meetings (due to the possible tax implications of accounting unification), it is clear how Confindustria had been trying to protect business 
from the possible implications of the deployment of a discretionary inspection power exercised by the Ministry of Corporations in assessing business costs. This is also connected with the fear of industrials about a lack of professionalism both at industrial and Governmental level in making an appropriate 'cost for pricing' assessment by the uniform costing: it is emphasized how the accounting unification had been realized slowly in Germany and developed in a context that was technically prepared, while the position of Italy appeared backward (DOC. December 12, 1941).

Concerning the role of the Italian academy, several foremost scholars took part in the Commission as long as it worked, thus contributing to add consistency to the scientific foundation of the solutions that were proposed. The Uniconti Commission constituted an opportunity for the Italian accounting community to offer a fine example of scientific contribution on relevant accounting and cost accounting themes. The Commission faced important issues, which represent prominent research areas in the accounting field still nowadays (e.g. if considering regulated sectors such as telecommunications, energy distribution or transports): normal profitability and profit, capital cost, cost allocation principles and techniques, asset evaluation. These issues, as the paper has pointed out, were discussed during the thirties in articles of the Italian Accounting Review and in textbooks by leading Italian scholars.

In this perspective, the Uniconti Commission experience shows how in a political and ideological totalitarian context and in a wartime economy - that established restrictions 
and targets (price control, planned economy) - a space was opened for economic and business doctrines to explore advancements with respect to principles, criteria and tools for accounting standardisation. The Italian doctrine offered its theoretical and technical knowledge to contribute in the identification of uniform accounting development. This happened without a detachment from the affirmed principles of Italian Economia aziendale, as the corporative ideology did not deny the role of private enterprise into economy and the legitimation of profit (Cinquini, 2007).

As it has been illustrated and discussed in the paper, the interplay between the domains of politics and ideology, accounting knowledge and techniques and economic and social interests implied remarkable reflections on the outcomes of the Commission.

This especially happened if considering the case of the rules on price setting. Price setting is characterized by high uncertainty and has not a unique solution justifiable in a technical perspective. In this case, the adoption of political stances can ultimately influence how rules of cost measurement are set and how cost-based prices are consequently determined. The cases discussed in the paper of depreciation and product costs-prices rules show clearly how the interests of each part involved in their design and implementation have been taken in consideration.

Hence, the technical solutions adopted into the uniform costing system for pricing can be considered as a result of the interplay between actors and their objectives: the objectives of the business and accounting academy (economic rationality and technical coherence), 
the interests of Business representatives (maintain profit), the dominant ideology (State regulated economy) and the political targets (price control). Power relations have been analyzed taking into account these types of objectives. The steps of the uniform costing system design where this process became more evident have been examined in the paper, claiming that the emerging cost accounting choices cannot be interpreted only through the lenses of the economic rationality and technical coherence.

Finally, the paper addresses the experience of fixing uniform cost accounting principles in Italy in the last century, so contributing in the stream of accounting history research on the uniform accounting trends that affected industrialized countries since the beginning of the last century (Mueller, 1965).

As noted above, the Uniconti Commission did not conclude its work because of the dramatic progress of the Second World War in Italy since 1943. As a consequence, not only we lack a complete picture of the outcomes of cost determination criteria in all the industrial sectors, but due to the radical changes in the institutional conditions and the new economic priorities after the war - namely, the 'post-war reconstruction' phase - we have no practical application of the uniform costing principles for a real evaluation of their efficacy. Nevertheless, the judgement on the theoretical validity of the results of the work conducted by the Commission did not change among Italian academicians after the war, regardless of any reason that had inspired its establishment and of the possible political implications deriving by the involvement with the Fascist regime ${ }^{14}$. 
More broadly, the research presented in this paper shows the relevance of an archival accounting history research in the perspective of "new" accounting history. In particular, the case of the Uniconti Commission addresses the potential of this approach applied to the accounting history in the context of the totalitarian States of the last century, a context which is still not widely studied. Away from taken-for-granted or a-priori judgements, a focus on accounting within these contexts in the perpective proposed in this paper may reveal to some extent unexpected and fruitful results, confirming the richness, complexity and un-linearity of the process of accounting change in historical perspective. 


\section{References}

Ahmed MN and Scapens RW (2003) The evolution of Cost-based Pricing Rules in Britain: an institutionalist perspective. Review of Political Economy 15: 173-191.

Amaduzzi A (1943) Sul controllo dei costi aziendali (On the control of company costs). Rivista Italiana di Ragioneria 26 (march/april): 29-35.

Amodeo D (1941) I costi comuni nell'aspetto funzionale (Overhead costs in functional aspect). Milano: Giuffrè.

Amodeo D (1964) Ragioneria Generale delle imprese (Accounting in enterprises). Giannini: Napoli.

Antinori C (2003) I Maestri, le teorie nella Rivista Italiana di Ragioneria e di Economia Aziendale dal 1901 al 2000 (Masters and theories in the Italian Journal of Accounting and Business Economics from 1901 to 2001). Roma: RIREA.

Anthony MT, Merino BD, Neimark MD (1982) The normative origins of positive theories: Ideology and accounting thought, Accounting, Organizations and Society 7(2):167-200

Aquarone A (2003) L'organizzazione dello Stato totalitario (The organization of the totalitarian State). Torino: Einaudi.

Armstrong P (1987) The rise of accounting controls in British capitalist enterprises, Accounting, Organizations and Society 12(5): 415-436

Bazzichi O and Vommaro R (1990) Guida all'archivio storico della Confindustria (1910-1945) (Guide to the historical Confindustria archive (1910-1945)). Roma: Sipi.

Besta F (1922) La Ragioneria (Accounting). Milano: Vallardi.

Bisman JA (2012), Surveying the landscape: The first 15 years of Accounting History as an international journal. Accounting History, 17(1): 5-34.

Burchell S, Clubb C, Hopwood AG, Hughes J and Nahapiet J (1980), The roles of accounting in organizations and society. Accounting, Organizations and Society 5(1): 5-27.

Camodeca R (2005) Le professioni economiche in Italia dall'ascesa ai problemi della globalizzazione ("Economic professions in Italy from the rise to the problems of globalization"). In AA.VV. (Ed.) Atti del VII Convegno Nazionale SISR. Roma: RIREA.

Canziani A (1994) Gino Zappa (1879-1960). Accounting revolutionary. In J. R. Edwards (Ed.), Twentieth-century accounting thinkers. London/New York: Routledge: 142-165.

Carnegie GD and Napier CJ (1996) Critical and interpretive histories: insights into accounting's present and future through its past. Accounting, Auditing \& Accountability Journal 9(3): 739.

Carnegie GD and Napier CJ (2012) Accounting's past, present and future: the unifying power of history. Accounting, Auditing \& Accountability Journal 25(2): 328-369.

Carli G (1941) Disciplina di guerra di prezzi e costi in Germania (War discipline of prices and costs in Germany). Rivista Italiana di Scienze Economiche 13(5): 1-23.

Cassese S (1974) Corporazioni e intervento pubblico nell'economia (Corporations and public intervention in economy). In Aquarone A and Vernassa M (Eds.) Il regime fascista. Bologna: Il Mulino.

Ceccherelli A (1936) Il problema dei costi nelle prospettive economiche e finanziarie delle imprese (The problem of costs in the economic and financial perspectives of companies). 
Firenze: Seeber.

Cinquini L (2007) Fascist Corporative Economy and Accounting in Italy during the Thirties: Exploring the relations between a Totalitarian Ideology and Business Studies. Accounting, Business and Financial History 17(2): 209-241.

Cinquini L, Giannetti R and Tenucci A (2009), Economia di guerra e cambiamenti della contabilità: l'unificazione dei conti e della determinazione dei costi nell'esperienza della Commissione "Uniconti" (1941-42) [War economy and changes in accounting: the unification of accounting and costing in the experience of the Commission "Uniconti" (1941-42)]. Contabilità e Cultura Aziendale 9 (1): 73-103.

Cooper C (1995) Ideology, Hegemony and Accounting Discourse: A Case Study of the National Union of Journalists Critical Perspectives on Accounting, 6(3): 175-209.

De Felice R (2001) Mussolini. Il duce (II). Lo Stato totalitario (Mussolini, the duce. The totalitarian State). Torino: Einaudi.

De Minico L (1935) Elasticità e relazioni dinamiche dei costi nelle imprese industriali (Elasticity and dynamic relationships of costs in industrial companies). Napoli: Rondinella.

De Minico L and D'ippolito T (1943) Il problema dei costi e dei prezzi e l'unificazione contabile nella economia di guerra (The problem of costs and prices and the accounting unification in the war economy). Rivista di Politica Economica 2 (febbraio): 62-76.

D'ippolito T (1935). I costi di produzione nelle aziende industriali (Production costs in industrial companies). Milano: Giuffrè.

D'ippolito T (1952) L'unificazione contabile (The accounting unification). Palermo: Abbaco.

Donnini V (1938) Dall'economia corporativa alla economia aziendale (From corporative economy to business economics). Rivista Italiana di Ragioneria gennaio (1): 24-28.

Fabrizi C (1942) Controllo dei costi e formazione dei prezzi nell'attuale disciplina legale tedesca (Cost control and pricing in current German legal discipline). Rivista bancaria delle assicurazioni e dei servizi tributari 1(gennaio): 1-15.

Fleischman RK, Mills PA and Tyson TN (1996) A Theoretical Primer For Evaluating and Conducting Historical Research in Accounting. Accounting History 1(1): 55-75.

Flower J (1996) Schmalenbach, Zappa and Limperg: three 'accounting heroes' of Continental Europe. In: Lapsley I (Ed.) Essays in Accounting Thought: a tribute to WT Baxter. Glasgow: The Institute of Chartered Accountants of Scotland, pp. 173-192

Foucault M (1977) Discipline and Punish: The Birth of the Prison. Harmondsworth: Penguin.

Foucault M (1982) The subject and the power, (Afterword) in Dreyfus, H.L. and Rabinow, P. (Eds), Michael Foucault: Beyond Structuralism and Hermeneutics, University of Chicago Press, Chicago IL: 208-226.

Franck L (1990) Il corporativismo e l'economia dell'Italia fascista (Corporatism and the economy of Fascist Italy). (N. Tranfaglia Ed.) Torino: Boringhieri.

Frei N (2002) Lo Stato nazista (The nazist State). Torino: Laterza.

Galassi G (2002) Concern Economics (Economia Aziendale). The Italian research tradition. In: 9th World Congress of Accounting Historians, Melbourne, Australia, 30 July-2 August 2002.

Giannessi E (1935) I costi di produzione nelle aziende tessili cotoniere (Production costs in the cotton textile companies). Firenze: Seeber.

Giannessi E (1943) Costi e prezzi-tipo nelle aziende industriali (Costs and prices in industrial 
companies). Milano: Giuffrè.

Gilling DM (1976) Accounting and Social Change. The International Journal of Accounting Spring: 59-71.

Hopwood AG (1983) On trying to study accounting in the contexts in which it operates. Accounting, Organizations and Society 8(2/3): 287-305.

Hopwood AG (1987) The archaeology of accounting systems. Accounting, Organizations and Society 12(3): 207-234.

Hopwood AG, Burchell S and Clubb C (1979) The development of accounting in its international context: past concerns and emergent issues. In Roberts A (Ed.) An Historical and Contemporary Review of the Development of International Accounting. Atlanta: Georgia State University, pp. 19-36.

Jucius M J (1944) Historical Development of Uniform Accounting. The Journal of Business of the University of Chicago 16(4): 219-229.

Kearins K and Hooper K (2002) Genealogical method and analysis. Accounting, Auditing \& Accountability Journal 15:733-757.

Loft A (1986) Towards a Critical Understanding of Accounting: The Case of Cost Accounting in the U.K., 1914-1925. Accounting, Organization and Society 11:137-169.

Matz A (1940a) Accounting as a Tool for Economy in German Business. The Accounting Review 15: $177-185$.

Matz A (1940b) Cost accounting in Germany. The Accounting Review 15: 371-379.

Miller P (1990) On the interrelations between accounting and the state. Accounting, Organizations and Society 15(4): 315-338.

Miller P, Hopper TM and Laughlin RC (1991) The New Accounting History: an introduction. Accounting, Organizations and Society 16(5/6): 395-403.

Miller P and Napier C (1993) Genealogies of Calculation. Accounting, Organization and Society 18:631-647.

Mitchell F and Walker SP (1996) Propaganda, attitude change and uniform costing in the British printing industry, 1913-1939. Accounting, Auditing \& Accountability Journal. 9(3): 98126.

Mitchell F and Walker SP (1997) Market pressures and the development of costing practice: the emergence of uniform costing in the U.K. Printing industry. Management Accounting Research 8: 75-101.

Mueller G (1965) International Experience with Uniform Accounting. Law and Contemporary Problems 30: 850-873.

Napier CJ (2006) Accounts of change: 30 years of historical accounting research. Accounting, Organizations and Society 31: 445-507.

Pacces FM (1934) I costi industriali (Industrial costs). Torino: Istituto di Studi Aziendali.

Parker LD (1997) Informing historical research in accounting and management: Traditions, philosophies, and opportunities. The Accounting Historian Journal 24(2): 111-149.

Parker LD (1999) Historiography for the new millennium: adventures in accounting and management. Accounting History 4(2): 11-42.

Previts GJ, Parker LD and Coffman EN (1990a) An Accounting Historiography: Subject Matter and Methodology. Abacus 26(2): 136-158.

Previts GJ, Parker LD and Coffman EN (1990b) Accounting History: Definition and Relevance. 
Abacus 26(1): 1-16.

Robson K, Willmott H, Cooper D, Puxty T (1994) The ideology of professional regulation and the markets for accounting labour: Three episodes in the recent history of the U.K. accountancy profession. Accounting, Organizations and Society 19(6): 527-553.

Rossi E (1966) I padroni del vapore (The bosses of steam). Bari: Laterza.

Santarelli A (1938a) Autarchia economica ed organizzazione aziendale (Economic autarky and company organization). Rivista Italiana di Ragioneria febbraio (2): 43-46.

Santarelli A (1938b) Autarchia, prezzi, costi (Autarky, prices, costs). Rivista Italiana di Ragioneria 10: 327-328.

Santomassimo G (2006) La terza via fascista. Il mito del corporativismo (The third fascist way. The myth of corporatism). Roma: Carocci.

Sarti R (1971) Fascism and the Industrial Leadership in Italy 1919-1940. Berkeley, CA: University of California Press.

Singer HW (1943) Standardized Accountancy in Germany. New York: Garland Publishing.

Solomons D (1950) Uniform Cost Accounting - A survey. Economica 17(67): 237-253.

Stewart RE (1992) Pluralizing Our Past: Foucault in Accounting History. Accounting, Auditing \& Accountability Journal, 5(2): 57-73.

Trovati A (1938) L'azienda nello stato corporativo (The company in the corporative State). Rivista Italiana di Ragioneria ottobre (5): 170-171.

Viganò E and Mattesich R (2007) Accounting research in Italy: second half of the 20th century. Review of Accounting and Finance 6(1): 24-41.

Walker S (2000) Encounters with Nazism: British accountants and the fifth international congress on accounting. Critical Perspectives on Accounting. 11(2): 215-245.

Zappa G (1927) Tendenze nuove negli studi di ragioneria (New trends in accounting studies). Milano: Istituto Editoriale Scientifico.

Zappa G (1937) Il reddito di impresa. Scritture doppie, conti e bilanci di aziende commerciali (Business income. Double-entry bookkeeping, accounts and balance sheets of commercial companies). Milano: Giuffrè.

Zelinschi D (2009) Uniform Costing: A Recurring Concern?. In: $32^{\text {nd }}$ Annual Congress of the European Accounting Association, 12-15 May 2009, Tampere. 


\section{Appendix 1 - Archival Sources examined}

\begin{tabular}{|c|c|c|c|}
\hline Acronym & Date & Title (English translation) & Notes \\
\hline DOC. & $\begin{array}{c}\text { December 12, } \\
1941\end{array}$ & $\begin{array}{l}\text { "Promemoria per il direttore: Unificazione della contabilità } \\
\text { aziendale" (Memo for the Director: Uniform accounting) }\end{array}$ & \\
\hline DOC. & $\begin{array}{l}\text { January16, } \\
1942\end{array}$ & $\begin{array}{l}\text { "Appunto per il direttore dell'ufficio "Servizi generali della } \\
\text { direzione": Riunione preparatoria di Milano alla seduta del } \\
\text { 15.1.1942" (Note for the Director of "Direction general } \\
\text { services": Preparatory meeting of Milan at the meeting of } \\
\text { 15.1.1942") }\end{array}$ & \\
\hline DOC. & $\begin{array}{l}\text { January28, } \\
1942\end{array}$ & $\begin{array}{l}\text { "Utilizzazione degli ammortamenti delle imprese industriali } \\
\text { per il finanziamento della guerra" (Use of the amortizations of } \\
\text { industrial companies for financing the war) }\end{array}$ & $\begin{array}{l}\text { Studio dell'ufficio } \\
\text { "Servizi generali della } \\
\text { direzione" }\end{array}$ \\
\hline DOC. & March 1942 & $\begin{array}{l}\text { "Relazione di Guido Carli sul viaggio in Germania" (Report of } \\
\text { Guido Carli on his journey to Germany) }\end{array}$ & \\
\hline DOC. & $\begin{array}{l}\text { May26, } \\
1942\end{array}$ & $\begin{array}{l}\text { "Processo verbale della seconda riunione tenutasi presso la } \\
\text { Confederazione Fascista degli Industriali" (Minutes of the } \\
\text { second meeting held by the Fascist Confederation of } \\
\text { Industrialists) }\end{array}$ & \\
\hline DOC. & $\begin{array}{l}\text { May26/27, } \\
1942\end{array}$ & $\begin{array}{l}\text { Convegno fra la ReichsgruppeIndustrie e la Confindustria, } \\
\text { Roma (Conference between ReichsgruppeIndustie and } \\
\text { Confindustria, Rome) }\end{array}$ & \\
\hline DOC. & $\begin{array}{l}\text { November9, } \\
1942\end{array}$ & "Appunto per il direttore" (Note for the Director) & \\
\hline DOC. & 1942 & $\begin{array}{l}\text { "Note illustrative dello schema generale della contabilità } \\
\text { unificata" (Explanatory notes on the general unified } \\
\text { accounting scheme) }\end{array}$ & $\begin{array}{l}\text { Stabilimento Grafico } \\
\text { Tiberino, Roma }\end{array}$ \\
\hline DOC. & 1942 & $\begin{array}{l}\text { "Criteri per la determinazione dei costi come base per la } \\
\text { fissazione dei prezzi dei prodotti nelle vendite da parte della } \\
\text { industria" (Costing principles to be used as a basis for fixing } \\
\text { the prices of products to be sold by the industry) }\end{array}$ & $\begin{array}{l}\text { Stabilimento Grafico } \\
\text { Tiberino, Roma }\end{array}$ \\
\hline DOC. & n.d. & $\begin{array}{l}\text { "Prima relazione al Ministro delle Corporazioni sulla } \\
\text { unificazione della contabilità in Germania" (First report to the } \\
\text { Minister of Corporationson the unification of accounting in } \\
\text { Germany) }\end{array}$ & \\
\hline DOC. & n.d. & $\begin{array}{l}\text { "Ordinamento della contabilità generale e delle } \\
\text { determinazioni dei costi nelle aziende dell'industria } \\
\text { siderurgica e metallurgica" (General accounting and costing } \\
\text { regulations applicable to the iron and steel industry) }\end{array}$ & \\
\hline DOC. & n.d. & $\begin{array}{l}\text { "Posizione della contabilità nel quadro del movimento tedesco } \\
\text { di razionalizzazione" (Position of accounting in the framework } \\
\text { of the German rationalization movement) }\end{array}$ & \\
\hline DOC. & n.d. & $\begin{array}{l}\text { "Osservazioni sul costo di produzione da considerare agli } \\
\text { effetti della determinazione del prezzo di vendita" } \\
\text { (Observations on production cost to be considered for price } \\
\text { setting) }\end{array}$ & \\
\hline
\end{tabular}




\begin{tabular}{|c|c|c|c|}
\hline DOC. & n.d. & "Appunto: Ordine di discussione" (Note: Order of discussion) & \\
\hline DOC. & n.d. & $\begin{array}{l}\text { "Osservazioni sui criteri di determinazione dei costi proposti } \\
\text { dalla Commissione per l'unificazione della contabilità" } \\
\text { (Observations on costing criteria proposed by the Commission } \\
\text { for uniform accounting) }\end{array}$ & \\
\hline DOC. & n.d. & $\begin{array}{l}\text { "Tabulati per la contabilità unificata" (Printouts for uniform } \\
\text { accounting) }\end{array}$ & \\
\hline LET. & $\begin{array}{l}\text { December 29, } \\
1941\end{array}$ & $\begin{array}{l}\text { Letter from Minister of Corporations (Renato Ricci) to: } \\
\text { Ministerof Finance, Fascist Party National Directorate, } \\
\text { Minister of Justice (Achille Grandi) and President of the } \\
\text { Council of Ministers }\end{array}$ & \\
\hline LET. & $\begin{array}{l}\text { January10, } \\
1942\end{array}$ & $\begin{array}{l}\text { Letter from Minister of Justice (Achille Grandi) to Minister of } \\
\text { Corporations (Renato Ricci) }\end{array}$ & \\
\hline LET. & $\begin{array}{c}\text { January12, } \\
1942 \\
\end{array}$ & Letter to Minister of Corporations (Renato Ricci) & \\
\hline LET. & $\begin{array}{l}\text { February19, } \\
1942\end{array}$ & $\begin{array}{l}\text { Letter from Industrial Fascist Corporation Director (Giovanni } \\
\text { Balella) to Minister of Corporations (Renato Ricci) }\end{array}$ & \\
\hline LET. & June 1942 & $\begin{array}{l}\text { Letter from Uniconti Commission secretary (Guido Carli) to } \\
\text { Minister of Corporations (Renato Ricci) }\end{array}$ & \\
\hline MIN. & $\begin{array}{c}\text { December, } 13 \\
1941\end{array}$ & Minutes of Uniconti Commission meeting & 1st meeting \\
\hline MIN. & $\begin{array}{l}\text { December, } 22 \\
1941\end{array}$ & Minutes of Uniconti Commission meeting & $\begin{array}{l}\text { 2nd meeting (with } \\
\text { hydroelectric power } \\
\text { plants) }\end{array}$ \\
\hline MIN. & $\begin{array}{c}\text { December, } 23 \\
1941 \\
\end{array}$ & Minutes of Uniconti Commission meeting & $\begin{array}{l}\text { 3rd meeting (with wollen } \\
\text { textile producers) }\end{array}$ \\
\hline MIN. & $\begin{array}{c}\text { January, } 15 \\
1942\end{array}$ & Minutes of Uniconti Commission meeting & $\begin{array}{l}\text { 4th meeting (with } \\
\text { steelworks) }\end{array}$ \\
\hline MIN. & $\begin{array}{l}\text { April 30, } \\
1942\end{array}$ & Minutes of Uniconti Commission meeting & 10th meeting \\
\hline MIN. & $\begin{array}{c}\text { May1, } \\
1942\end{array}$ & Minutes of Uniconti Commission meeting & 11th meeting \\
\hline
\end{tabular}

DOC.$=$ Document

LET. $=$ Letter

MIN. $=$ Minutes

n.d. = no date 


\section{Appendix 2 - Meetings of the 23 Sub- Commissions created in 1942 (until November 7,1942 )}

\begin{tabular}{|c|c|c|c|c|}
\hline Sub-Commission & $\begin{array}{c}\text { Number of } \\
\text { members }\end{array}$ & First call & Second call & Third call \\
\hline Wool & 8 & July 27 & 5 September & \\
\hline Silk & 8 & July 27 & August 3 & September 2 \\
\hline Canvas, Linen and flowers & 5 & July 27 & September 9 & \\
\hline Textiles & 12 & July 27 & September 5 & \\
\hline Cotton & 6 & July 27 & September 10 & September 29 \\
\hline Carbonated water & 6 & August 3 & September 4 & \\
\hline Food and agriculture & 13 & August 3 & September 5 & \\
\hline Hydrothermal & 5 & August 3 & September 15 & \\
\hline Milk, Pasta, Rice, etc. & 19 & August 3 & September $9 / 10$ & \\
\hline Wine, alcohol and the like & 6 & August 4 & September 11 & October 15 \\
\hline Sugar & 6 & August 4 & September 12 & \\
\hline Electrical communications & 5 & August 10 & September 15 & \\
\hline Electrical companies & 8 & August 10 & September 16 & \\
\hline Artificial textile fibres & 5 & September 2 & September 28 & \\
\hline Glass and ceramics & 4 & September 3 & October 15 & \\
\hline Chemicals & 80 & $\begin{array}{c}\text { September3 } \\
\text { September } 14\end{array}$ & $\begin{array}{c}\text { September } 29 / \\
\text { October } 1 \\
\text { October } 2 / 3 \\
\text { October } 16 / 17 / 23\end{array}$ & \\
\hline Iron and Steel & 17 & September $6 / 7$ & & \\
\hline $\begin{array}{l}\text { Cement, Plaster, Lime and } \\
\text { Bricks }\end{array}$ & 8 & September 16 & October 21 & \\
\hline Building & 4 & September 16 & & \\
\hline Wood & 4 & September 16 & October 20 & \\
\hline Mining & 9 & September 14 & October 22 & \\
\hline Marble and stone & 6 & September 14 & October 23 & \\
\hline Mechanical & 91 & $\begin{array}{c}\text { September } \\
18 / 19 / 30\end{array}$ & & \\
\hline Total & 335 & & & \\
\hline
\end{tabular}




\section{Notes}

${ }^{1}$ In the U.K. cost standardization was promoted in specific industries or economic categories with the objective to improve price control and at the same time preventing their reduction below manufacturing costs (Mitchell and Walker, 1996 and 1997). In France, the uniform costing issue arose in the same way and about at the same time (i.e. at the turn of the 20th century) as in UK. Here, the Cegos (General Commission on the Scientific Organisation of Labour) gave a fundamental contribution in proposing to standardize cost calculation. Formed mainly by engineers and entrepeneurs representatives, the Cegos' main goal was to spread and improve rational organization methods (Zelinschi, 2009). In the United States, the printers' association issued a Standard Uniform Cost Finding System for Printers in 1910, as an attempt at considering the problem of the "increased production costs and consequent increased rates" (Solomons, 1950: 239).

${ }^{2}$ The documentation at the base of this research is filed in the historical archives of Confindustria b.94, f.1 - Unificazione della contabilità e costi di produzione (Bazzichi and Vommaro, 1990). The following acronyms will be used throughout the paper: MIN. $=$ minutes, DOC. $=$ document, LET. $=$ letter.

${ }^{3}$ The construction of "corporative economy" was presented as an alternative to socialism and as a model for overcoming both "liberal economics" and the "Marxist class struggle". "Corporative economy" would have been implemented through a self-government of the representatives of economic categories of different trade and industrial sectors (Fascist corporations), which should be established as organs of the government, without abolishing private companies but regulating and planning the economic activities. Most historiographers agree that Corporatism was essentially a sound theoretical construction, but totally unrealized: the Charter of Work (issued on April 30th, 1927) - i.e. the Economic Constitution of Fascism that outlined the basis of the Fascist corporative system - was considered by eminent jurists to be a presentation of principles that lacked mandatory effects. One evidence of the distance between corporative principles and the practice of government action is the fact per se that corporative institutes were created later and had no further power of enforcement: the 1926 decrees issued to create Fascist corporations and the relevant ministry remained inoperative, only in 1930 a National Council of Corporations was founded, while fascist corporations were not created until 1934 (Cassese, 1974; De Felice, 2001: p. 11).

${ }^{4}$ Zappa was an innovator of accounting content in Italy and stressed quantitative determinations as the focus of this discipline. We refer here briefly about his contribution in Italian accounting thought, leaving the deepening by the references reported. In Zappa's view the central accounting issue is income determination. His idea shifts the principal focus of attention from the balance sheet to the income statement, i.e. the recognition of the relevance of the income statement and the dynamic aspect of accounting for income calculation, therefore proposing a new 'sistema del reddito' (income-based accounting system) (Zappa, 1937). In this way, he breaks away from the vision of an income statement as an aggregation of 'partial results' linked by specific individual assets (Besta, 1922); instead, income is seen to arise from the entire complex of transactions, and cannot be referred to separate individual assets or classes of assets. However, these could not live separately from business organisation and management, otherwise outcome would have been pure formalism: Zappa believed that organisation and management disciplines should be joined to accounting (Zappa, 1927: p. 20). Economia aziendale is therefore an overall doctrine, regarding business as a complex whole; its main features can be summarised in these general points (Flower, 1996: pp. 181182): it covers all forms of economic organisation at all levels (the house-hold, the business firms, public enterprises and towns, up to the State). The word azienda is a generic term, often translated as 'concern'; it aims at developing the general principles that govern the equilibrium of the azienda as a coherent unity. Zappa's contribution is characterised by a 'radical holistic approach' based on a 'unitary view of the azienda' (see: Canziani, 1994; Flower, 1996; Galassi, 2002; Zan, 1994). 
${ }^{5}$ See Cinquini, 2007 to deepen the contribution of these scholars within the influence of Fascist ideology
in Italy. 6 “'(...) there is a generally acknowledged limitation of the 'political principle': all (Italian) scholars reaffirm the need for the independence of management principles in the firm. This basic condition was to be applied to the fascist corporation regulative regime as well: 'fascist corporations' should remain outside the boundaries of business management, both in terms of doctrinal references and in terms of the practice of the corporative experience.”(Cinquini, 2007: p.234)

${ }^{7} \mathrm{An}$ analysis of archival evidence revealed that the following professors took part in that meetings: Giovanni Balella, Teodoro D'Ippolito, Carlo Fabrizi, Giancarlo Frè, Remo Malinverni, Pietro Onida, Francesco Maria Pacces, Renato Teani, Mario Saibante, and Pasquale Saraceno. Attending chartered accountants were: Ghezzi, Ghiglione, and Maggiore. Guido Carli, future governor of the Bank of Italy, was the secretary of the Commission. Some meetings also saw the presence of manufacturers, such as hydroelectric power plants (Edison, Adriatica, Sip, Valdarno, Terni), woollen textile producers (Marzotto, Rivetti, Tollegno) and steelworks (Finsider, Ilva, Terni, S.I.A.C., Dalmine, Falck, Fiat, Breda).

${ }^{8}$ The following academicians were involved: Giovanni Balella, Teodoro D'Ippolito, Carlo Fabrizi, Giancarlo Frè, Remo Malinverni, Pietro Onida, Francesco Maria Pacces, Renato Teani, Mario Saibante, and Pasquale Saraceno. Four of them will be fundamental references in the post WWII development of accounting and business studies in Italy: Pietro Onida, Teodoro D'Ippolito, Pasquale Saraceno (all Gino Zappa's scholars) and Federico M. Pacces.

${ }^{9}$ DOC., "First report to the Minister of Corporations on the unification of accounting in Germany".

${ }^{10}$ It is the agreement of October 2, 1925 stipulated between Confindustria and the Fascist labour union. With this agreement, the industrial sector recognized the Fascist labour union as the only representative of workers. This was the first step of the Fascist regime towards a total control and regulation of trade-union activities.

${ }^{11}$ The cost accounting rules proposed by the Commission reflect the main point of Zappa's thought centered on 'unitary view of the azienda' Another evidence of this coherence is in the document 'Iron and steel industry cost regulation" analyzed in the next section, where is stated that one of the aim of the document is the (p.1): “(...) final determination of costs, revenues and results that can be abstractly allocated to the productions considered". The term "abstractly" seems just recalling the Zappa's 'radical holistic approach' (see footnote 4).

${ }^{12}$ Differently De Minico and D'Ippolito, (1943: p.65) interpret the acceptable price proposed in the document as the result of economic-technical-cost plus a remuneration for the general economic business risk.

${ }^{13}$ In the documents and internal reports used by the Commission, the position of the two Authors is in line with the German position. See. Carli (1941: pp. 22-23); DOC., "First report to the Ministry of Corporations on the German uniform accounting process", internal report of the Uniconti Commission, pp. 36-37. Based on this documentary evidence, we can see how the decree issued on March 5, 1940 by the Reich's Commissioner had established criteria for the determination of economic results obtained by the businesses for the purpose of ascertaining whether these exceeded normal results and therefore could be considered, to a certain extent, as over-profits. Moreover, business owners were liable and required to review the prices, costs and profits of their organisations during the war period (Preisbilanz) and, if they had obtained overprofits, they had to transfer them to the Uffici di Finanza (Finance offices), thus adjusting prices to costs.

${ }^{14}$ As two of the major Italian scholars stated: "The cost determination criteria proposed by the abovementioned Commission, though in their close connection with the companies' daily lives and flexibility, reflect the results of the stated theories" (D'Ippolito, 1952: pp. 41-42). "The financial accounting scheme proposed for the manufacturing industry (...) is the original, simple but effective, output of Italian minds. It is appropriate for both small/medium concerns and for the largest industrial corporations, because it includes reductions to be adapted to different requirements. But, most of all, it corresponds to the most 
recent developments in bookeeping and business statistics theories". (De Minico and D'Ippolito, 1943: p. 73). See also Amodeo, 1964: pp. 989 ff. 